\title{
Potensi Mie dari Labu Kuning (Cucurbita moschata Durch) dalam Menurunkan Kadar Glukosa Darah
}

\section{Potential of Noodle from Yellow Pumpkin (Cucurbita moschata Durch) to Reducing Blood Glukose Level}

\author{
Muh. Ikhlas Arsul ${ }^{*}$, Nur Rezky Rutami Amir ${ }^{2}$, Ruhul Fadila², Indah Nur Pratiwi², Fitril \\ Imani $^{2}$
${ }^{1}$ Jurusan Farmasi Fakultas Kedokteran dan Ilmu Kesehatan Universitas Islam Negeri Alauddin Makassar, J1 H.M. Yasin Limpo No.36 Kecamatan Sombaopu Kabupaten Gowa, Sulawesi Selatan ${ }^{2}$ Mahasiswa Prodi Farmasi Fakultas Kedokteran dan Ilmu Kesehatan Universitas Islam Negeri Alauddin Makassar, Jl H.M. Yasin Limpo No.36 Kecamatan Sombaopu Kabupaten Gowa, Sulawesi Selatan

Kontak*: ikhlas.arsul@uin-alauddin.ac.id

\begin{abstract}
ABSTRAK
Penelitian ini bertujuan untuk mengetahui potensi labu kuning dalam menurunkan kadar gula darah setelah dibuat dalam bentuk makanan (mie). Labu terlebih dahulu dikupas lalu diiris tipis-tipis kemudian dikeringkan. Setelah kering labu dijadikan tepung dengan cara digiling dan diayak. Tepung labu kemudian diolah menjadi mie dengan mencapurkan dengan tepung kaya protein dan telur lalu digiling hingga membentuk mie. Mie dibuat dengan perbandingan tepung labu 57, 67, dan 75\% terhadap total bahan padat. Mie dengan kandungan tepung labu $75 \%$ menunjukkan penurunan kadar glukosa darah tertinggi yaitu $60 \mathrm{mg} / \mathrm{dL}$ dengan indeks glikemik 69,56. Dari hasil pengujian hedonik, responden sebagian besar menyukai mie yang terbuat dari labu kuning.
\end{abstract}

Kata Kunci : Labu kuning, diabetes, glukosa darah

\section{ABSTRACT}

The purpose of this research is to determine the potential of pumpkin in food form (noodle) to reducing the blood sugar level. First, pumpkin is peeled and cut into thin slices and then dried to make flour. After drying, the pumpkin is milled and sieved. Then, pumpkin flour made into noodle by mixing it with high-protein flour and eggs, and then milled into noodle. Noodle are made with 57, 67 and 75\% pumpkin flour from the total bulk. Noodle with pumpkin content $75 \%$ showed the highest decrease of blood sugar level which is $60 \mathrm{mg} / \mathrm{dL}$ with a glycemic index 69.56. According to the results of the hedonistic tests, most person likes pumpkin noodle.

Keywords : Yellow pumpkin, diabetic, blood glucose

\section{PENDAHULUAN}

Saat ini masalah kesehatan telah bergeser dari penyakit infeksi ke penyakit degeneratif. Beberapa penyakit degenaratif antara lain hipertensi, diabetes melitus, jantung koroner, osteoporosis, dan lain sebagainya. Penyebabnya kebanyakan diakibatkan perubahan gaya hidup, pola makan, faktor lingkungan, kurangnya aktivitas fisik.
Penyakit degenaratif yang meningkat dapat mempengaruhi angka kematian (Handajani, Roosiehermiatie, \& Maryani, 2010). Salah satu kebiasaan masyarakat saat ini yakni mengonsumsi makanan cepat saji dan cemilan yang manis seperti kue, teh manis, dan yang mengandung lemak tinggi seperti daging, keju, mentega, susu, gorengan, coklat, dan lain sebagainya. 
Diabetes mellitus adalah kelainan metabolisme kronis yang ditandai dengan hiperglikemia. Yang dapat menyebabkan komplikasi mikrovaskuler dan neuropati. Menurut International Diabetes Federation (IDF) jumlah kasus diabetes mellitus di Indonesia pada tahun 2011 adalah 366 juta dan diperkirakan akan meningkat pada 2030 menjadi 552 juta (Withing, Leonor, Clara, \& Jonathan, 2011).

Penderita diabetes mellitus adalah sekelompok kecil di masyarakat yang membutuhkan perhatian khusus dalam pemberian makanan dalam sehari-hari. Penderita diabetes memiliki kadar glukosa darah yang melebihi batas normal atau disebut juga hiperglikemia. Penyakit ini disebabkan oleh produksi insulin yang rendah. Insulin berperan dalam mengubah glukosa menjadi sumber energi dan menyinkronkan lemak. Diabetes mellitus adalah kelainan metabolisme kronis yang ditandai dengan hiperglikemia. Yang dapat menyebabkan komplikasi mikrovaskuler dan neuropati (Gary, et al., 2011). Salah satu upaya yang dapat dilakukan pada penderita diabetes adalah dengan mengatur pola makan yang sehat dengan mengonsumsi makanan yang mengandung serat yang tinggi dan mengandung komponen senyawa antidiabetes dalam bentuk makanan seperti mie yang terbuat dari labu kuning.

Labu kuning (Cucurbita moschata) merupakan pangan lokal yang banyak dikonsumsi oleh masyarakat sebagai sayuran dan kue. Selain itu labu kuning memiliki bukti ilmiah mampu mengontrol kadar glukosa pada pasien diabetes mellitus karena pada labu mengandung serat yang tinggi dan senyawa antidiabetes yaitu antioksidan yang dapat menghambat aktivitas radikal bebas akibat hiperglikemik dan flavonoid yang dapat mengurangi resistensi insulin, meningkatkan sensitivitas insulin dan menghalangi aktivitas enzim alpha amylase dan alpha glucosidase (Hawa \& Murbawani, 2015; Fathonah, Indriyanti, \& Kharisma, 2014; Dewi, Wijaya, \& Wijayahadi, 2011). Selain itu beberapa penelitian pada tikus yang dibuat diabetes menunjukkan ekstrak labu kuning memberikan efek hipoglikemik dan bertindak sebagai antidiabetes. Ekstrak labu kuning dan bubuk bijinya dapat memperbaiki sel-sel pangkreas yang rusak dan produksi insulin (Makni, et al., 2010; Gary, et al., 2011).

Labu kuning banyak dibudidayakan di negara-negara Afrika, Amerika, India, dan Cina. Tanaman ini mampu tumbuh di dataran rendah maupun tinggi dengan ketinggian antara $0 \mathrm{~m}-1500 \mathrm{~m}$ diatas permukaan laut (Rukmana, 1997). Di Indonesia khususnya kota Makassar, produksi labu kuning sangat melimpah.

Berdasarkan uraian diatas maka dilakukan penelitian tentang potensi mie dari labu kuning dalam menurunkan kadar glukosa darah penderita diabetes. Penelitian ini bertujuan untuk mengetahui potensi labu kuning dalam menurunkan kadar gula darah 
setelah dibuat dalam bentuk makanan dalam hal ini adalah mie.

\section{METODE PENELITIAN}

\section{Pembuatan Tepung Labu}

Labu yang digunakan diperoleh dari Pasar Samata, Kabupaten Gowa Provinsi Sulawesi Selatan. Labu terlebih dahulu dibersihkan dan dikupas kulitnya lalu dicuci dengan air, setelah itu diiris tipis dan dikeringkan di lemari pengering pada suhu $\pm 40^{\circ} \mathrm{C}$ selama 48 jam. Setelah kering, labu kemudian digiling dengan mesin penggiling dan diayak dengan ayakan nomor mesh 100 hingga diperoleh tepung labu.

\section{Pembuatan Mie}

Tepung labu masing-masing kelompok dengan jumlah 100, 200 dan $300 \mathrm{~g}$, dicampur dengan tepung kaya protein $100 \mathrm{~g}$ dan 1 butir telur, kemudian ditambahkan air secukupnya sedikit demi sedikit sambil diaduk hingga membentuk adonan. Adonan kemudian dimasukkan ke dalam alat cetak untuk membentuk mie. Komposisi mie dapat dilihat pada tabel 1 .

\section{Uji Penurunan Kadar Glukosa Darah}

Pengujian kadar glukosa darah menggunakan probandus kategori sehat

Tabel 1. Komposisi mie

\begin{tabular}{cccc}
\hline & \multicolumn{3}{c}{ Komposisi } \\
\cline { 2 - 4 } Formula & $\begin{array}{c}\text { Labu } \\
\text { kuning } \\
(\mathrm{g})\end{array}$ & $\begin{array}{c}\text { Tepung } \\
\text { kaya protein } \\
(\mathrm{g})\end{array}$ & $\begin{array}{c}\text { Telur } \\
\text { (butir) }\end{array}$ \\
\hline I $(50 \%)$ & 100 & 100 & 1 \\
II $(67 \%)$ & 200 & 100 & 1 \\
III $(75 \%)$ & 300 & 100 & 1 \\
\hline
\end{tabular}

sebanyak 4 orang dengan lama pengujian 13 hari. Masing-masing probandus terlebih dahulu diadaptasikan dengan memberikan makanan yang mengandung glukosa selama 7 hari pertama. Pada hari ke-8 hingga hari ke 12, tiga orang probandus masing-masing diberi makan mie formula I, II, dan III sebanyak $100 \mathrm{~g}$ dua kali sehari pada saat pagi dan sore hari, sedangkan probandus lainnya mengkonsumsi nasi. Pengukuran glukosa darah dilakukan mulai hari ke-9 pada saat pagi hari sebelum mengkonsumsi apapun kecuali air putih hingga hari ke-13.

Hasil pemeriksaan respon glukosa darah disajikan dalam bentuk tabel dan kurva. Luas area di bawah kurva dihitung melalui metode trapesium menggunakan program Microsoft Office Excel. Metode trapezoid dilakukan dengan cara menjumlahkan semua luas bangun trapesium dalam kurva respon glukosa darah. Luas bangun trapezium (LT) dihitung dengan rumus:

$$
L T=\frac{\text { jumlah dua sisi sejajar }}{2} \times \text { tinggi }
$$

Nilai indeks glikemik (IG) dihitung dengan menggunakan rumus:

$$
I G=\frac{A U C \text { Uji }}{\text { AUC kontrol }} \times 100 \%
$$

dimana $A U C \quad U j i=$ luas area di bawah kurva glukosa darah makanan uji dan $A U C$ kontrol = luas area di bawah kurva glukosa darah makanan standar.

\section{Uji Hedonik}

Pengujian hedonik melibatkan 30 responden dimana masing-masing responden 
memberikan penilaian dengan skala numerik 1 (tidak suka) sampai 5 (sangat suka) untuk rasa, aroma, warna dan tekstur.

\section{HASIL DAN PEMBAHASAN}

Hasil dari respon glukosa darah dari subjek yang digunakan setelah mengkonsumsi mie yang dibandingkan dengan mengkonsumsi nasi sebanyak $100 \mathrm{~g}$ dapat dilihat pada tabel 2. Data hasil pengukuran pada tabel 2 menunjukkan penurunan glukosa darah selama 5 hari setelah mengkonsumsi mie Formula I, II dan III dengan kadar glukosa darah berturut-turut sebesar $20 \mathrm{mg} / \mathrm{dL}, 30$ $\mathrm{mg} / \mathrm{dL}$, dan 60mg/dL. Sedangkan pada subjek yang mengkonsumsi nasi, glukosa darah meningkat sebesar $20 \mathrm{mg} / \mathrm{dL}$. Penurunan glukosa darah tertinggi ditunjukkan pada mie Formula III. Namun, Formula I menunjukkan pengurangan atau penurunan yang lebih kecil dibandingkan dengan Formula II. Gambar 1 menunjukkan kurva respons glukosa darah, dimana terjadi penurunan kadar glukosa darah pada kelompok pengkonsumsi mie sementara yang mengkonsumsi nasi terjadi peningkatan glukosa darah.

Penelitian sebelumnya yang dilakukan oleh Yoshinari menjelaskan bahwa ekstrak metanol labu kuning dapat menurunkan kadar glukosa darah berdasarkan tes toleransi

Tabel 2. Penurunan kadar glukosa darah setelah pemberian mie dari labu kuning

\begin{tabular}{ccccccc}
\hline \multirow{2}{*}{ Kelompok } & \multicolumn{4}{c}{ Kadar Glukosa Darah Hari Ke- } & \multirow{2}{*}{$\begin{array}{c}\text { Penurunan Kadar } \\
\text { Glukosa Darah }\end{array}$} \\
\cline { 2 - 5 } & 9 & 10 & 11 & 12 & 13 & $20(+)$ \\
Nasi & 190 & 198 & 204 & 210 & 210 & $20(-)$ \\
Formula I (50\%) & 180 & 173 & 172 & 163 & 160 & $30(-)$ \\
Formula II (67\%) & 200 & 194 & 187 & 172 & 170 & $60(-)$ \\
Formula III (75\%) & 170 & 155 & 144 & 126 & 110 & \\
\hline
\end{tabular}

Keterangan: $\quad$ Penurunan kadar glukosa darah dihitung berdasarkan selisih antara kadar glukosa darah hari ke-13 dengan kadar glukosa darah hari ke-9

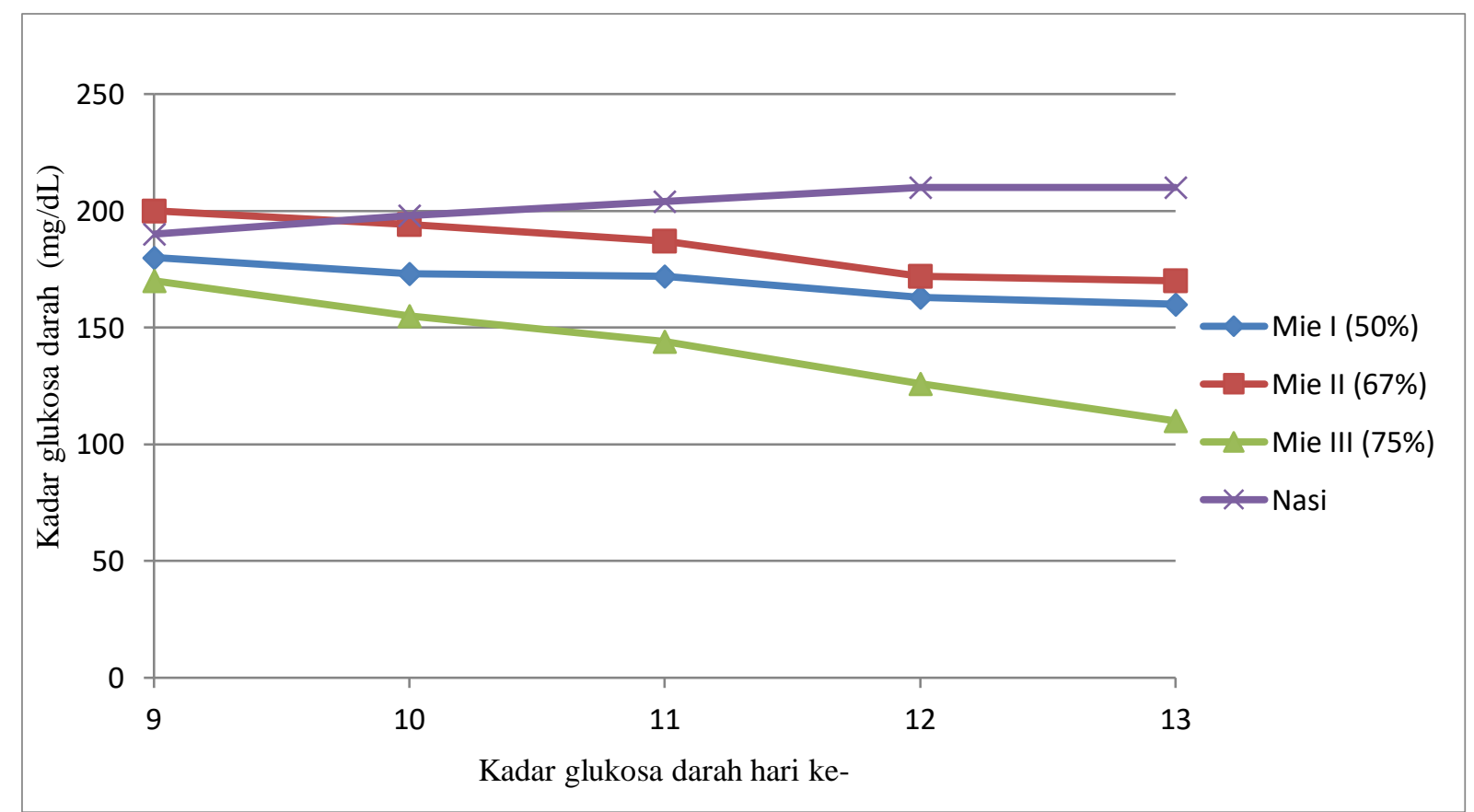

Gambar 1. Grafik penurunan kadar glukosa darah. 
Tabel 3. Indeks glikemik mie dari labu kuning

\begin{tabular}{ccc}
\hline Kelompok & Indeks Glikemik & Klasifikasi \\
\hline Formula I (50\%) & 83.49 & Tinggi \\
Formula II (67\%) & 90.88 & Tinggi \\
Formula III $(75 \%)$ & 69.58 & Sedang \\
\hline
\end{tabular}

Keterangan : IG $<55=$ Rendah, IG 55-70 = Sedang, IG $>70=$ Tinggi

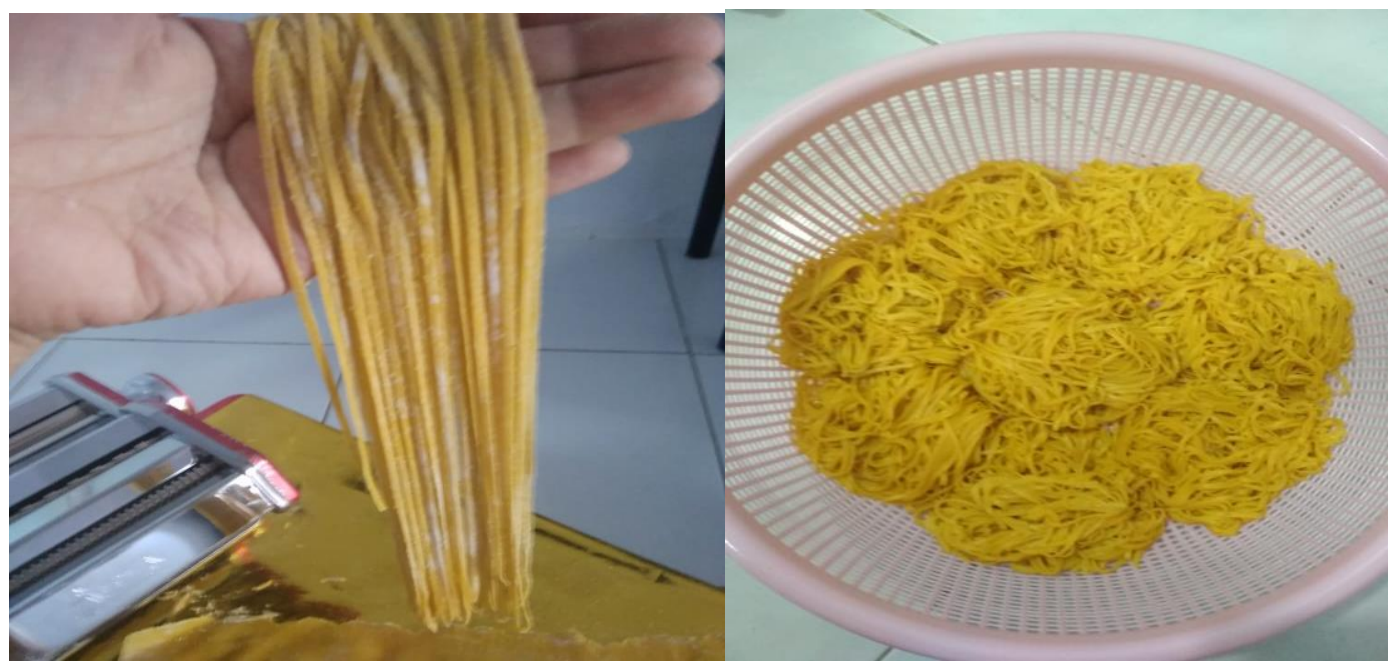

Gambar 2. Mie dari labu kuning

glukosa oral pada tikus dengan dosis 107 $\mathrm{mg} /$ hari selama 14 hari. (Yoshinari, Sato, \& Igarashi, 2009). Penelitian yang sama juga dilakukan oleh Rahmi (2014) menggunakan ekstrak air labu kuning dapat menurunkan glukosa darah pada tikus dengan rentang dosis efektif 56 - $112 \mathrm{mg} / 200 \mathrm{gBB} /$ hari yang diberikan secara peroral. Ekstrak air labu kuning dapat menurunkan glukosa darah sebesar 107,57 - 228,28 mg/dL setelah pemberian selama 14 hari. Dosis tersebut diperoleh berdasarkan konversi dosis rata-rata yang digunakan pada masyarakat yakni 160 g/hari (Fathonah, Indriyanti, \& Kharisma, 2014).

Berdasarkan penelitian lainnya dan yang diperoleh dalam penelitian ini, labu kuning dapat menurunkan glukosa darah baik dalam bentuk ekstrak maupun dalam bentuk makanan. Penurunan glukosa tertinggi pada ekstrak adalah $228,28 \mathrm{mg} / \mathrm{dL}$ sedangkan pada mie sebesar $60 \mathrm{mg} / \mathrm{dL}$. Perbedaan lama waktu pemberian dan subjek penelitian merupakan faktor yang mempengaruhi perbedaan penurunan kadar glukosa darah tersebut.

Pengukuran indeks glikemik dengan menggunakan metode trapesium dapat dilihat pada tabel 2. Formula I, II dan III menghasilkan indeks glikemik berturut-turut 83,49; 90,88; dan 69,58. Indeks glikemik terendah adalah mie labu kuning III dengan nilai 69,58, termasuk dalam kategori sedang. Sedangkan mie dengan labu kuning I dan II dikategorikan tinggi.

Labu kuning mengandung senyawa betakaroten, flavonoid, vitamin $\mathrm{C}$ dan vitamin $\mathrm{E}$ adalah antioksidan yang menghambat aktivitas radikal bebas yang menyebabkan retensi insulin. Flavonoid berperan dalam menurunkan retensi insulin dan 
Tabel 4. Hasil uji hedonik mie dari labu kuning

\begin{tabular}{clllllll}
\hline \multirow{2}{*}{ Parameter } & 1 & 2 & 3 & 4 & 5 & \multirow{2}{*}{ Rata-rata } \\
\cline { 2 - 5 } & 0 & 0 & 3 & 21 & 6 & 4,1 \\
Rasa & 0 & 0 & 4 & 18 & 8 & 3,9 \\
Warna & 0 & 0 & 6 & 21 & 3 & 4,1 \\
Aroma & 0 & 0 & 4 & 18 & 8 & 4,1 \\
Tekstur & $-1=$ tidak suka, $2=$ agak tidak suka, $3=$ agak suka, $4=$ suka, $5=$ sangat suka. \\
\hline Keterangan : & - Nilai rata-rata dihitung menggunakan rumus $\overline{\mathrm{x}}=\frac{\sum_{i}^{n}=1 x_{i}}{n}$ & &
\end{tabular}

menungkatkan sensitivitas insulin. Selain itu flavonoid juga memiliki efek hipoglikemik dengan cara memblok aktivitas enzim alfa amilase dan alfa glukosidase sehingga produksi glukosa menurun. Prinsip penghambatan ini menyebabkan penundaan pemecahan karbohidrat dan disakarida, menghambat absorbsi glukosa, dan menghambat metabolisme sukrosa menjadi glukosa serta fruktosa. Mekanisme ini memiliki kesamaan aksi mekanisme seperti akarbose yang selama ini digunakan sebagai obat untuk penanganan diabetes melitus.

Pada uji hedonik, responden dimintakan tanggapan pribadinya tentang kesukaan atau ketidaksukaannya terhadap suatu produk. Selain itu responden juga mengemukakan tingkat kesukaannya. Adapun skala pengujian hedonik yaitu sangat suka (5), suka (4), agak suka (3), agak tidak suka (2), dan tidak suka (1). Tingkat kesukaan inilah yang merupakan parameter suatu produk dapat diterima oleh masyarakat.

Berdasarkan tabel 4, sebanyak 21 orang suka dengan rasa dan aroma dari mie dan 18 orang suka dengan warna dan teksturnya. Sebanyak 6 orang sangat suka dengan rasa dari mie, 8 orang sangat suka dengan warna dan teksturnya, dan 3 orang sangat suka dengan aromanya. Sebanyak 3 orang agak suka dengan rasa mie, 4 orang agak suka dengan warna dan teksturnya, dan 6 orang agak suka dengan aromanya. Hasil pengujian hedonik menunjukkan sebanyak 30 responden menyukai rasa, warna, aroma dan tekstur dari mie dengan nilai rata-rata berturut-turut adalah 4,$1 ; 3,9 ; 4,1$; dan 4,1 .

\section{KESIMPULAN}

Mie dengan Formula III (75\% tepung labu) menunjukkan penurunan kadar glukosa darah tertinggi yaitu $60 \mathrm{mg} / \mathrm{dL}$ dengan indeks glikemik 69,56. Berdasarkan uji hedonik meliputi rasa, warna, tekstur dan aroma yang dilakukan mie dari labu kuning disukai oleh masyarakat.

\section{DAFTAR PUSTAKA}

Dewi, M., Wijaya, I., \& Wijayahadi, N. (2011). Ekstrak Bawang Putih ( Allium sativum) dan Ekspresi Insulin serta Derajat Insulitis Pangkreas Tikus Sprague-Dawley yang Diinduksi Streptozotocin. Media Medika Indonesia, 45(2), 105-112. Retrieved from https://ejournal.undip.ac.id/index.php/mmi /article/view/3022/2705

Fathonah, R., Indriyanti, A., \& Kharisma, Y. (2014). Labu Kuning (Curcubita moschata Durch.) untuk Penurunan Kadar Glukosa Darah Puasa pada Tikus Model Diabetik. 
Global Medical and Healt Communication, 27-33. doi:10.29313/gmhc.v2i1.1527

Gary, G., Shahwar, I., Sheng, W., Abubaker, M., Samil, K., David, A., . . Stephen, E. (2011, March 16). The Hypoglycaemic Effect of Pumpkins as Anti-diabetic and Functional Medicines. Food Research International, 44(4), 862-867. doi: 10.1016/j.foodres.2011.03.016

Handajani, A., Roosiehermiatie, B., \& Maryani, H. (2010). Faktor-faktor Yang Berhubungan dengan Pola Kematian. Buletin Penelitian Sistem Kesehatan, 13(1), 42-53.

Hawa, I., \& Murbawani, A. (2015, October 1). . Pengaruh Pemberian Formula Enteral Berbahan Dasar Labu Kuning (Cucurbita moschata Durch) Terhadap Kadar Glukosa Darah Posrprandial Tikus Diabetes Mellitus. Journal of Nutrition Collage, 4(4), 387-393.
Makni, M., Sefi, M., Fetoui, H., Garoui el, M., Gargouri, N., Boudawara, T., \& Zeghal, N. (2010, June 4). Flax and Pumpkin seeds mixture ameliorates diabetic nephropathy in rats. Food and Chemical Toxicology, 48(8-9), 2407-2412. doi:10.1016/j.fct.2010.05.079

Rukmana, R. (1997). Usaha Tani Labu. Yogyakarta: Kanisius.

Withing, D., Leonor, G., Clara, W., \& Jonathan, S. (2011). IDF Diabetes Atlas: Global estimates of the prevalence of diabetes for 2011 and 2030. Diabetes research and clinical practice 94(3), 3, 311-21. doi:10.1016/j.diabres.2011.10.029

Yoshinari, O., Sato, H., \& Igarashi, H. (2009). Anti-Diabetic Effects of Pumpkin and Its Components, Trigonelline and Nicotinic Acid, on Goto-Kakizaki Rats. Journal Bioscience, Biotechnology, and Biochemistry, 73(5), 1033-1041. doi: https://doi.org/10.1271/bbb.80805 